\title{
Contribution to the knowledge of minute brown scavenger beetles (Coleoptera: Latridiidae) from Belarus
}

\section{K познанию скрытников (Coleoptera: Latridiidae) Беларуси}

\author{
S.V. Saluk \\ C.B. Салук
}

Scientific-practical center of the National Academy of Sciences of Belarus for biological resources, Akademicheskaya Str. 27, Minsk 220072, Belarus. E-mail: ssaluk@yandex.by

Научно-практический центр НАН РБ по биоресурсам, ул. Академическая, 27, Минск 220072, Беларусь.

KEY WORDS: Coleoptera, Latridiidae, Belarus, new species, reestablished species, distribution.

КЛЮЧЕВЫЕ СЛОВА: Coleoptera, Latridiidae, новые виды, восстановленный вид, распространение.

ABSTRACT. Two new species of Latridiidae (Corticariinae) are described from Berezinsky Biosphere Reserve: Corticaria lukashuki sp.n. and C. rogneda sp.n. C. porochini C. Johnson, 2007 sp.rest. is reestablished from the synonymy of $C$. aphictoides Reitter, 1898. For the species: Dienerella ruficollis (Marsham, 1802), Enicmus alutaceus Reitter, 1885, Latridius gemellatus Mannerheim, 1844, Corticaria foveola (Beck, 1817), C. interstitialis Mannerheim, 1844 for the first time the localities are listed. Corticaria orbicollis Mannerheim, 1853 is excluded from the list of Belarusian Latridiidae, new localities are given for some rare species are.

РЕЗЮМЕ. Два новых для науки вида скрытников (Latridiidae: Corticariinae) описаны с территории Березинского биосферного заповедника: Corticaria lukashuki sp.n. и C. rogneda sp.n. Для пяти видов: Dienerella ruficollis (Marsham, 1802), Enicmus alutaceus Reitter, 1885, Latridius gemellatus Mannerheim, 1844, Corticaria foveola (Beck, 1817), C. interstitialis Mannerheim, 1844, впервые приведен локалитет, C. orbicollis Mannerheim, 1853 исключена из списка фауны жесткокрылых Беларуси, приведены новые локалитеты, для нескольких редких и малоизвестных видов. C. porochini C.Johnson, 2007 stat. rest. восстановлена из синонимов $C$. aphictoides Reitter, 1898.

\section{Introduction}

The last publication on the Cucujoidea of Belarus [Tsinkevich, 2005] contains information about 51 species of Latridiidae. Two following papers [Tsinkevich et al., 2005, Tsinkevich, 2007] added to this list additional two species.

During the last years I have accumulated substantial material on Belarusian latridiids. This material is used here to describe two new species, list geographic localities for the first time and add new localities for several uncommon species, correct some wrong identification records and also to reestablish the status of one synonymized species as valid.

Holotypes of the new species are deposited in the collection of the National Museum Natural History University of Oslo (Norway), paratypes and other material is kept in author's private collection .

\section{Result and discussion}

Family Latridiidae Erichson, 1842

Subfamily Latridiinae Erichson, 1842

Dienerella (Cartoderema) ruficollis (Marsham, 1802)

MATERIAL. 3 ex., Minsk Area, Molodechno Distr., Maksimovka vill. env., in a haystack, 20.vi.1990, S. Saluk leg.

NOTES. Recorded for Belarus for the first time. Report of this species for Vitebsk Area [Solodovnikov, 1999] is based on the wrong identification [Tsinkevich, 2000].

DISTRIBUTION. Subcosmopolite [Johnson, 2007].

\section{Enicmus alutaceus Reitter, 1885}

MATERIAL. $10^{7}$, Minsk Distr., Priluki vill., potatoes, 3.vii.1987, O. Aleksandrovich leg.

NOTES. First exact location for the species, previously it was reported for Belarus only [Saluk, 1995].

DISTRIBUTION. Europe: Romania, Belarus, Russia (South European Territory); Asia: Turkey, Iran, Kazakhstan, Western Siberia, Eastern Siberia, Mongolia, Russian Far East [Saluk, 1995; Johnson, 2007].

\section{Enicmus atriceps Hansen, 1962}

MATERIAL. 21 ex.: 3ex., Vitebsk Area, Berezinsky Biosphere Reserve, Domzheritsy forestry, comb. 284a, spruce forest (Piceetum oxalidosum), trunk traps on spruce stumps, 1.iv.-3.v.2014, A.O. Lukashuk lgt.; 8 ex., the same place, but 3.v.-2.vi.2014; 4 ex., the same place, but 2.vi.-1.vii.2014; 6 ex., the same place, but 1.vii.-4.viii.2014.

NOTES. The species was recorded previously for southeastern Belarus from Gomel Area, Mozyr town env. [Tsinkevich, 2007]. The new location expand north-eastern borders of the species range.

DISTRIBUTION. Europe: Denmark, France, Germany, Greece, Hungary, Italy, Poland, Romania, Slovakia, Switzerland [Johnson, 2007]. 


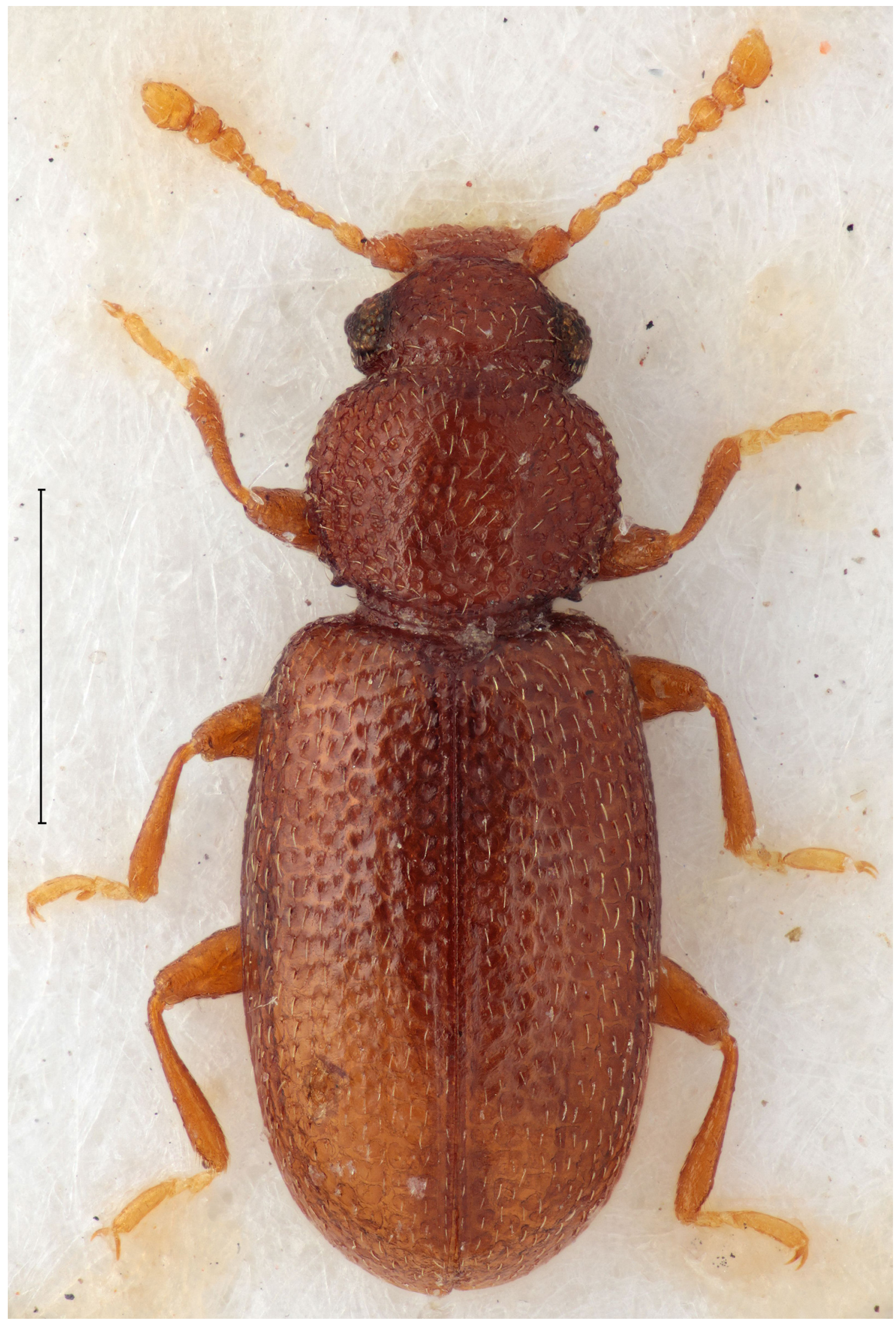

Fig. 1. Corticaria lukashuki sp.n.: paratypus, male, habitus. Scale bar: $0.5 \mathrm{~mm}$.

Pис. 1. Corticaria lukashuki sp.n.: паратип, самец, внешний вид. Масштаб - 0,5 мм. 


\section{Enicmus planipennis Strand, 1940}

MATERIAL. 7 ex.: 3 ex., Vitebsk Area, Berezinsky Biosphere Reserve, Kraytsy forestry, comb. 473, spruce forest (Piceetum oxalidosum), trunk traps, 2.v.-3.vi.2014, A.O. Lukashuk lgt.; 1 ex., 4 $\mathrm{km} \mathrm{S}$ from Vitebsk, mixed forest, in the bark of living pine, 16.i.1994, I.A. Solodovnikov lgt.; 1 ex., the some place, but 30.xi.1994; 1 ex., the some place, but 2.i.1995; 1 ex., the some place, but 21.ii.1995.

NOTES. The species was recorded from Berezinsky Biosphere Reserve [Saluk, 1991]. The record of this species for the Belarusian part of Bialoweza Primeval Forest [Tsinkevich, 1998, Tsinkevich et al., 2005] should be attributed to Enicmus rugosus (Herbst, 1790).

DISTRIBUTION. Europe: Austria, Belarus, Czech Republic, Finland, Germany, Latvia, Norway, Russia (Central and North European Territory), Sweden, Switzerland [Johnson, 2007, Bukejs et al., 2013].

\section{Enicmus testaceus (Stephens, 1830)}

MATERIAL. 9 ex.: 2 ex., Vitebsk Area, Berezinsky Biosphere Reserve, Domzheritsy foresty, comb. 284a, spruce forest (Piceetum oxalidosum), trunk traps on spruce stumps, 3.v-2.vi.2014, A.O. Lukashuk lgt.; the some place, 2 ex., but, 2.vi.-1.vii.2014; 5 ex., the some place, but 1.vii.-4.viii.2014.

NOTES. The species is more common in southern and western parts of Belarus, once a single specimen was recorded from Vitebsk env. [Solodovnikov, 1999], however, I have not seen this specimen.

DISTRIBUTION. Widely distributed in Europe, North Africa (Algeria, Canary Islands), Asia (Iran) [Johnson, 2007], also common in Caucasus [Saluk, unpublished].

Latridius gemellatus Mannerheim, 1844

nidicola (Palm, 1944)

MATERIAL. 2 ex., Vitebsk Area, Miorskiy Distr., State Sanctuary "Elnya", Elnianskiy ostrov vall., in Vespa crabro nest, 8.v.1997, I.A. Solodovnikov \& A.G. Sushko lgt.

NOTES. Recorded for Belarus for the first time. Previous record for Belarus [Johnson, 2007] is based on wrong interpretation of the "Catalogue of Coleoptera of Belarus" [Aleksandrovich et al., 1999].

DISTRIBUTION. Europe: Austria, Czech Republic, Denmark, Finland, Germany, Norway, Poland, Spain, Sweden, Switzerland [Johnson, 2007], Latvia [Bukejs et al., $2013]$.

\section{Subfamily Corticariinae Curtis, 1829}

\section{Corticaria foveola (Beck, 1817)}

MATERIAL. 2 ex., $5 \mathrm{~km} \mathrm{~S}$ from Vitebsk, mixed forest, in the pine bark, 22.ii. 1991, I.A. Solodovnikov lgt.

NOTES. Recorded for Belarus for the first time.

DISTRIBUTION. Europe (including Cental and North Territory of Russia), Asia: Turkey, Russian Far East [Johnson, 2007].

\section{Corticaria interstitialis Mannerheim, 1844}

MATERIAL. 2ex.: 1 female, Vitebsk Area, Berezinsky Biosphere Reserve, Savskiy Bor vill. env., comb. 435, pine forest (Pinetum pleuroziosum). 1 ex., Berzinsky Biosphere Reserve, Kraytsy forestry, dead part at the base of a pine tree, 17.iv.2002, S. Saluk lgt., $1 \sigma^{7}$, Berezinsky Biosphere Reserve, Kraytsy foresty, comb. 473, spruce forest (Piceetum oxalidosum), trunk traps, 30.vi.3.viii.2014, A.O. Lukashuk lgt.

NOTES. Recorded for Belarus for the first time.

DISTRIBUTION. Europe: Czech Republic, Finland, Germany, Norway, The Netherlands, Poland, Russia (Central European Territory), Sweden [Johnson, 2007].

\section{Corticaria lateritia Mannerheim, 1844}

MATERIAL. 10 ex.: 9 ex., Vitebsk Area, Berezinsky Biosphere Reserve, Savskiy Bor vill. env., comb. 435, pine forest (Pinetum pleuroziosum), in bark of dry pine tree, with fruiting bodies of Fomitopsis pinicola, 15-18.x.1995, S.Saluk, A.Lukashuk lgt.; 1 ex., Vitebsk Area, Gorodok Distr., Rudnya vill. env., mixed forest, in bark of dry pine tree infested with wood-destroying fungi, 15.iv.2010, S.Saluk lgt.

NOTES. Was recorded from Belarusian part of Bialoweza Primeval Forest [Tsinkevich et al., 2005].

DISTRIBUTION. Europe (including Central and North European Territory of Russia), Asia: Russian Far East [Johnson, 2007, Saluk, 1992].

\section{Corticaria lukashuki sp.n. \\ Figs 1-4}

TYPE MATERIAL. 10 ex. : Holotype: $\sigma^{7}$, Vitebsk Area, Berezinsky Biosphere Reserve, Savskiy Bor vill. env., comb. 435, pine forest (Pinetum oxalidosum), in bark of dry pine with fruiting bodies of Fomitopsis pinicola, 15-18.x.1995, S. Saluk, A. Lukashuk lgt.; Paratypes: $3 \sigma^{\top} \sigma^{\top}, 3$, 3 , the some place ; $2 \sigma^{\top} \sigma^{\top}, 1+$, the some place, but wetland pine forest (Pinetum ledoso-sphagnosum), under the bark of dead pine tree, 15.iv.1988, A. Lukashuk lgt.

DESCRIPTION. Body lengh 1.35-1.58 mm, moderately elongated, covered with sligthly curved, oppressed, pale setae of moderate length (Fig. 1), head breadth $0.29-0.35$ $\mathrm{mm}$, pronotal breadth $0.40-0.47 \mathrm{~mm}$, elythral breadth $0.55-$ $0.63 \mathrm{~mm}$, antennae length $0.45-0.50 \mathrm{~mm}$.

Body yellowish-red (young adults) to brown, legs yellowish-red to reddish-brown, tarsi and antennae yellowish-red.

Head 1.60-1.75 times as broad as long, with netted microsulpture, with fine and sparsely disributed punctures, which are dense and coarse in basal part; temples rather short, obtuse angled, equal approximately $1 / 4$ of eye diameter; antennal structure as in Fig. 2.

Pronotum 1.21-1.25 times as broad as long, broadest around middle, moderately curved, denticles of laterial side vary from fine, even and somewhat weakened to distinct and sharpened, are more prominent in basal thirdz; postmedian depression moderately developed, shallow; lateral impressions vary in shape and development; punctation of lateral sides dense and coarse, intervals are usually smaller than puncture diameters; punctuation of disc sparser, distance between punctures usually larger than their diameter; disc covered with rather sparse, short, oppressed, slightly curved setae.

Elytra moderately long, 1.50-1.63 time as long as wide, 2.52-2.75 time longer than pronotum, weakly oval, broadest near the middle, flattened, shiny ; punctuation uneven: striae at the base are set very close together, with large, dense, uneven, shallow, in some places double punctures, strongly weakened behind the middle; interstries narrow, with uneven large shallow punctures, often strial and intersrial punctuation appears intermingled. Hind wings fully developed.

Male: Pro- and mesotibia on apices with small ventral tooth, first protarsomere weakly widened. Aedeagus as in Figs 3-4.

ETYMOLOGY. Named in honour of my old friend, staff entomologist of the Berezinsky Biosphere Reserve Aleksander O. Lukashuk, who made this surprising discovery.

NOTES. Habitus, body, eye and temple sizes, pronotum shape, color and shine and to somewhat extent elytral sculpture of the new species presemble those of Corticaria inconspicua Wollaston, 1860. However, it can by diagnosed by the following characters: more flattened elytra with more parallel lateral sides and widely rounded apices, larger and denser punctuation of the elytral basal area, shorter and oppressed elytral rand and different shape of male genitalia; also, these 

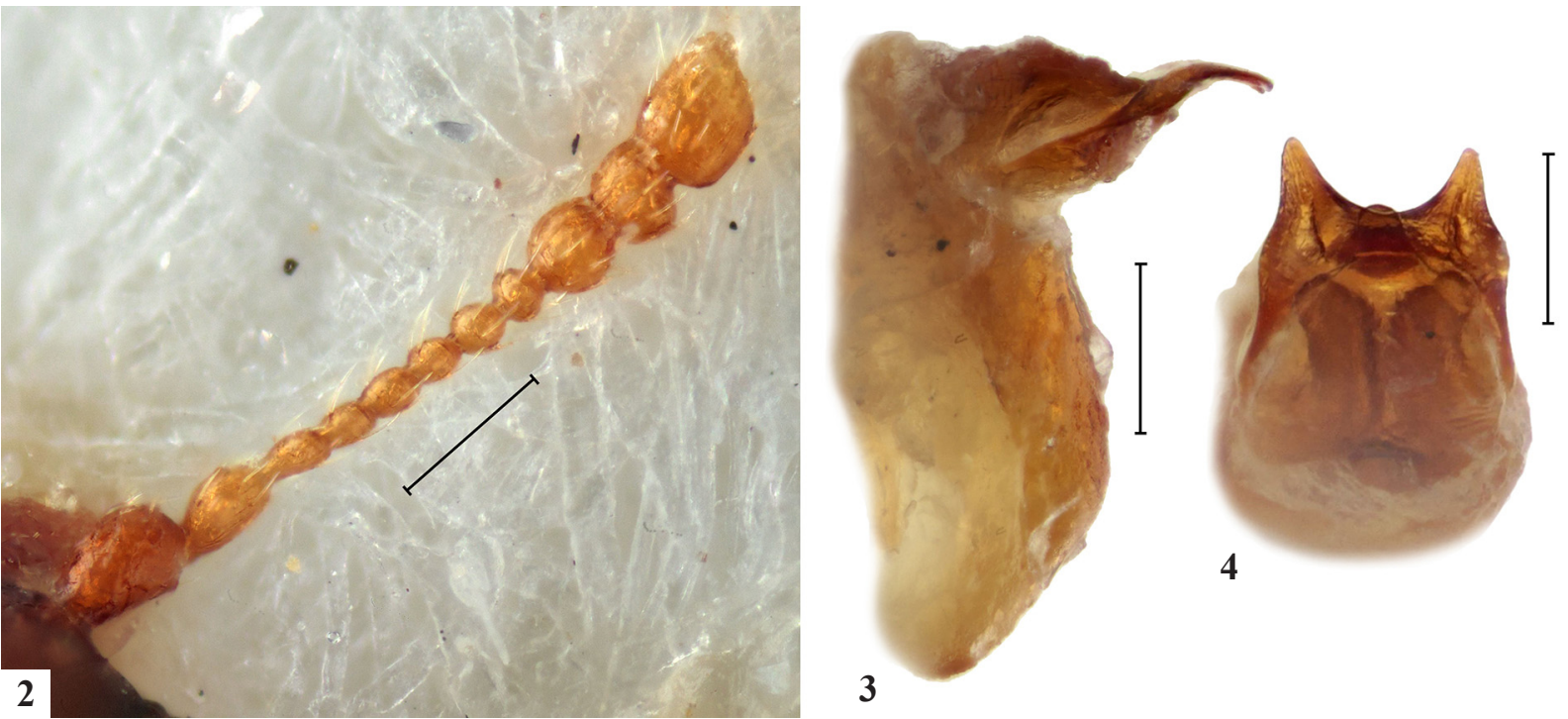

Figs 2-4. Corticaria lukashuki sp.n.: 2 - antenna; 3 - 4 aedeagus (3 - lateral view; 4 - dorsal view). Scale bars: 0.1 mm. Рис. 2-4. Corticaria lukashuki sp.n.: 2 - антенна; 3 - 4 эдеагус (3 - сбоку; 4 - сверху). Масштаб: 0,1 мм.

species have different habits. It should be noted that large specimens of new species (as in Fig.1) resemble Corticaria alleni C.Johnson 1974, which also has similar biology. C. alleni can be recognized by the following characters: much larger, $1.58-1.97 \mathrm{~mm}$, more elongate, elytral length 1.70-1.76 times higher than width of combined elytra and 2.8-3.0 time as long as pronotum, elytral striae with small, distinct, moderately dense punctures, distinct intrestriae regular, small, sparse punctures and different shape of aedeagus.

It seem worth of noting that the dead tree, where the type series of $C$. lukashuki was collected, also yielded four extra species of Corticaria on the same collecting event, $C$. alleni, C. polypori Sahlberg, 1900, C. lateritia, C. longicollis (Zettetstedt, 1838).

\section{Corticaria orbicollis Mannerheim, 1853}

NOTES. Original record of this species from Berezinsky Biospere Reserve [Saluk, 1991], as well as all later ciations [Aleksandrovich et al., 1999; Tsinkevich, 2004, 2005; Johnson, 2007] should be attributed to C. lukashuki sp.n., which has somewhat similar aedeagus shape.

C. orbicollis is not know fromn Belarus now and so should be excluded from the checklist of Belarusian Latridiidae, although its discovery in north-eastern part of Belarus seems to me quite possible.

Corticaria porochini C. Johnson, 2007 stat. rest.

MATERIAL. 4ex.,Vitebsk. Area, Berezinsky Biosphere Reserve, Domzheritsy forestry, Chistik vall., comb. 313, wetland birch forest (P.-Betuletum caricoso-sphagnosum), in a haystack, 10.ix.1994, S. Saluk, V. Rosenzweig lgt.

NOTES. Was recorded from Vitebsk Area [Solodovnikov, 1999].

Recently this species was synonimized with Corticaria aphictoides Reitter, 1898 [Rücker, 2013]. This nomenclature act was based exclusively on the $C$. aphictoides description, since the holotype was not found in Hungarian Natural History Museum (Budapest) at the moment. The holotype was rediscovered recently, and I have studied it (Fig. 5). The specimens has the following labels: "Mongolia bor. Reitter [printed] / C. aphictoides m. 1897 [handwritten, probably by
E. Reitter] / Urga [handwritten] / leg. Willberg [handwritten] / Holotypus [white label with red border, printed] / Corticaria aphictoides Reitter 1898 [handwritten]".

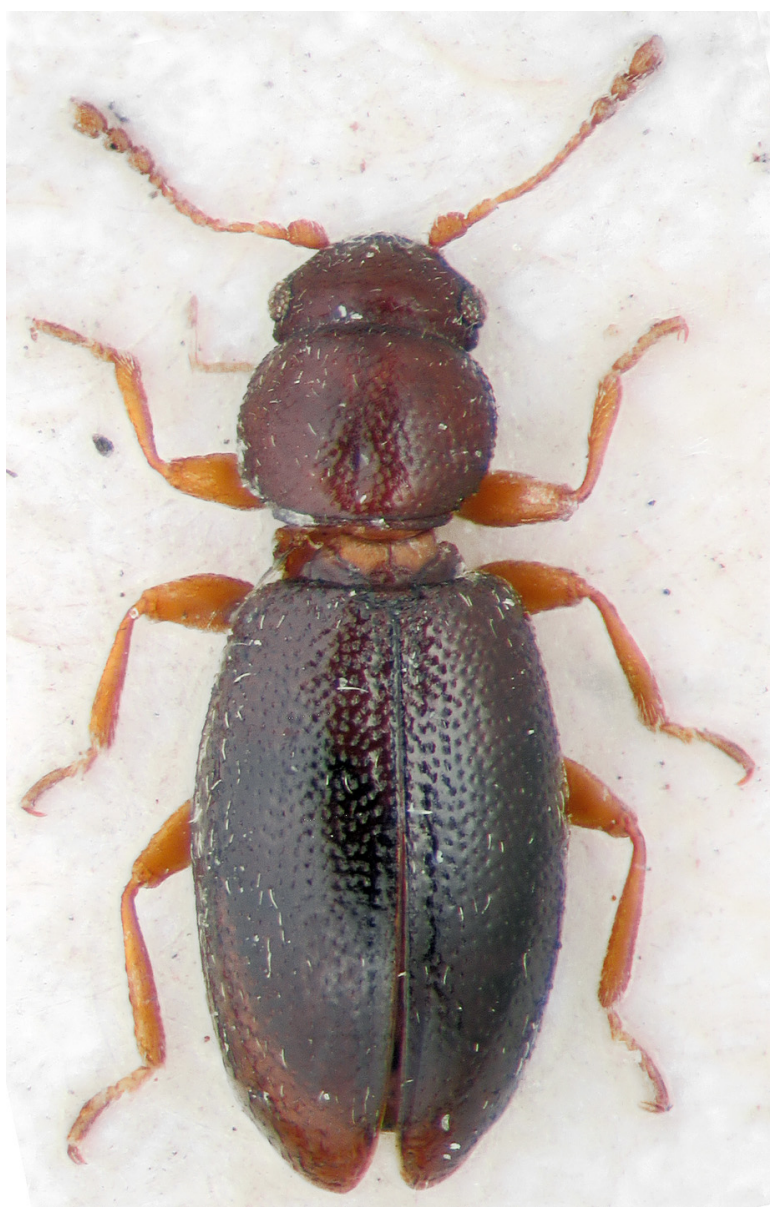

Fig. 5. Corticaria aphictoides Reitter, holotype female. Рис. 5. Corticaria aphictoides Reitter, голотип, самка. 
Rücker [2013] reproduced the original decription of $C$ aphictoides, which correspond precisely with the holotype features. It seems worth of citing a few characters from this description: « .. kastanienbraun, Flügeldecken schwarz, Fühler und Beine gelbrot.», «Kopf ... zwischen den Fühlern mit 2 seichten Eindrücken.», «Flügeldecken ... fein und dicht punktirt ... nicht gestreift, nur ein Nathstreif eingedrückt».
Following are important diagnostic characters for both species of concern. C. aphictoides: head and pronotum reddishbrown, elytra blackish with brownish tone basally and apically, tibia and antennae unicolorous, yellowish-red; head between antennae with two distinct depressions; elytra with small, dense, irregular punctures, striae indistinct, only longitudinal sutural depression with smal, even piunctures.

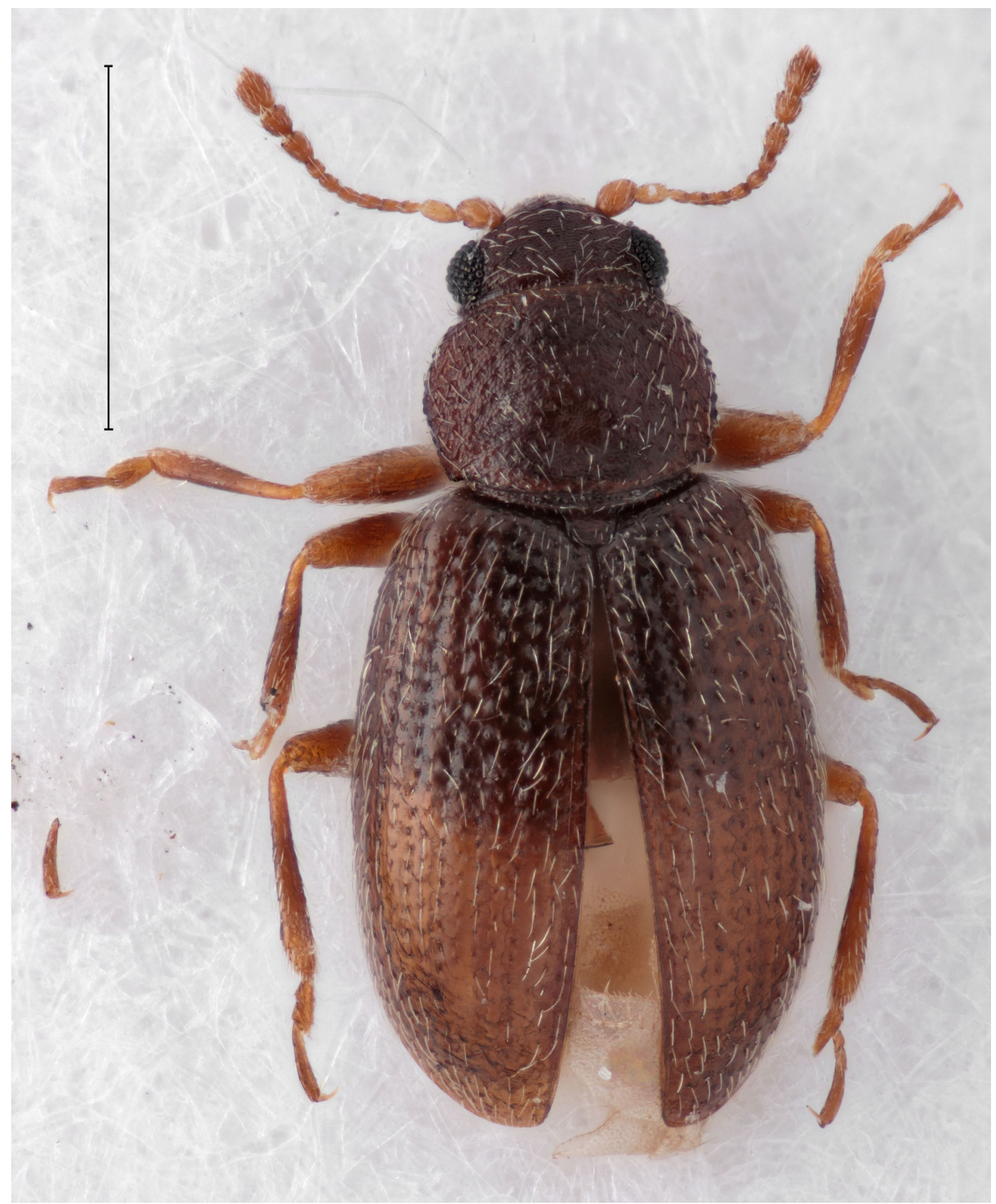

Fig. 6 . Corticarina rogneda sp.n.: holotypus, male, habitus. Scale bar: $0.5 \mathrm{~mm}$.

Рис. 6 . Corticarina rogneda sp.n.: голотип, самец, внешний вид. Масштаб: 0,5 мм. 
C. porochini: normaly head, pronotum and elytra black; tibia and tarsi (exept claw tarsomere) and antennae (firth to fourth antennomeres) yellowish-red, claw tarsomere and 5-11th antennomeres reddish-brown; head between antennae withoth depressions; elytra with distinct striae, interstrias wide, with small, sparse, even punctures.

C. aphictoides belongs to the "pubescens" group, characterized primarily by uneven, irregular elytral punctuation, in terms of setation (short, fine, sparse and oppressed) it is close to Corticaria dentiventris Poppius, 1903, C. kabakovi Saluk,1992, C. magadanica Tsinkevich, 2001. Weak shoulder knobs of oval, convex elytra suggest it is a montane flightless species. It was collected near Ulaanbaator ('Urga' is its old name) and most probably is local endemic species. Its closest realtive seems to be $C$. magadanica, a montane flightless speies as well, with smaller and more elongate body, smaller elytral punctures and paler antennae and legs.

Among the species I am familiar with, $C$. porochini is apparently the closest relative of C. amurensis Reitter, 1879 , similarly looking species, which can be distinguished by paler, yellowish-red body color, wider pronotum, les regular elytral punctuation and aedeagus shape, being apparently a vicariant species inhabiting lower Amur River basing and Primorky Territory of Russian Far East [Saluk, 2009].

DISTRIBUTION. Holarctic [Rücker, 2013].

\section{Corticarina rogneda sp.n.} Figs 6-9

TYPE MATERIAL. 3ex.: Holotype: $\sigma^{\top}$, Minsk Area, Borisov Distr., Berezinsky Biosphere Reserve, Palik forestry, Uvyazok vall., mixed forest, in leaf litter, 3.v.1987, S. Saluk lgt.; Paratype: $1 O^{\top}, 1$ o, the some place

DESCRIPTION. Body length 1.30-1.44 mm, moderately elongated (Fig. 6); head breadth including eyes $0.30-0.34$ $\mathrm{mm}$; pronotal breadth $0,40-0.50 \mathrm{~mm}$; elythral breadth 0.55 $0.63 \mathrm{~mm}$; antennal length $0.43-0.46 \mathrm{~mm}$. Colour reddishbrown (young beetles) to dark brown; leggs yellowish-red to reddish-brown; antennae yellowish basally (first three antennomeres) and reddish apically.
Head transverse, with netted microsulpture, distinct and sparsely distributed punctures. Temples short, distinct, their length equals to size of two eye facets, with fine erect setae apically. Antennal structure as in Fig. 7.

Pronotum 1.29-1.36 times as broad as long, lateral sides moderately curved, broadest around the middle, lateral sides finely, and almost uniformely crenulate; postmedian depressions moderately developed, lateral impressions variable, rounded or transverse; surface weakly shining, with rather deep netted microsulpture, punctures rather coarse, moderately dense, elongate, two times longer than wide, become more circular laterally.

Elytra elongate oval, 2.63-2.88 times as long as pronotum and 1.58-1.60 times as long as wide; lateral sides moderately curved; broadest around middle. Elytral striae rather strongly punctate in basal part, intervals between strial punctures equal or slightly larger their diameters; interstries shiny, slightly wider than striae, finely, sparsely punctured. Elytral pubescens sligthly curved, rather long $(0.06-0.07 \mathrm{~mm})$.

Male: anterior tibial tooth small, inconspicuous, situated ventrally, at approximately apical third. Aedeagus as in Figs 8-9.

ETYMOLOGY. Named in honour of legendary Rogneda, the $\mathrm{X}$ century Duchess of the Polotsk Principality, on the historic lands of which the Berezinsky Biosphere Reserve is situated.

NOTES. Among European Corticarina, this small species resembles Corticarina lambiana (Sarp, 1910), at the firast glance. Both occur sympatrically, have similar body sizes, however, C. lambiana is paler (reddish-brown), its pronotum has coarse and dense punctuation, with intervals much smaller the diameters of punctures and elytra are clearly oval, 1.29-1.31 times longer than wide.

Corticarina parvula (Mannerheim, 1844) is also similar to the new species in habitus, body, leg and antennal coloration, but C. parvula is larger on average $(1.38-1.53 \mathrm{~mm})$, has a transverse pronotum (1.14-1.30 times as long as wide), its elytra are relatively longer (2.75-3.07 times as long as pronotum) and somewhat more oval-shaped (1.46-1.54 times longer than wide). All three mentioned species have also differently shaped aedeagi.

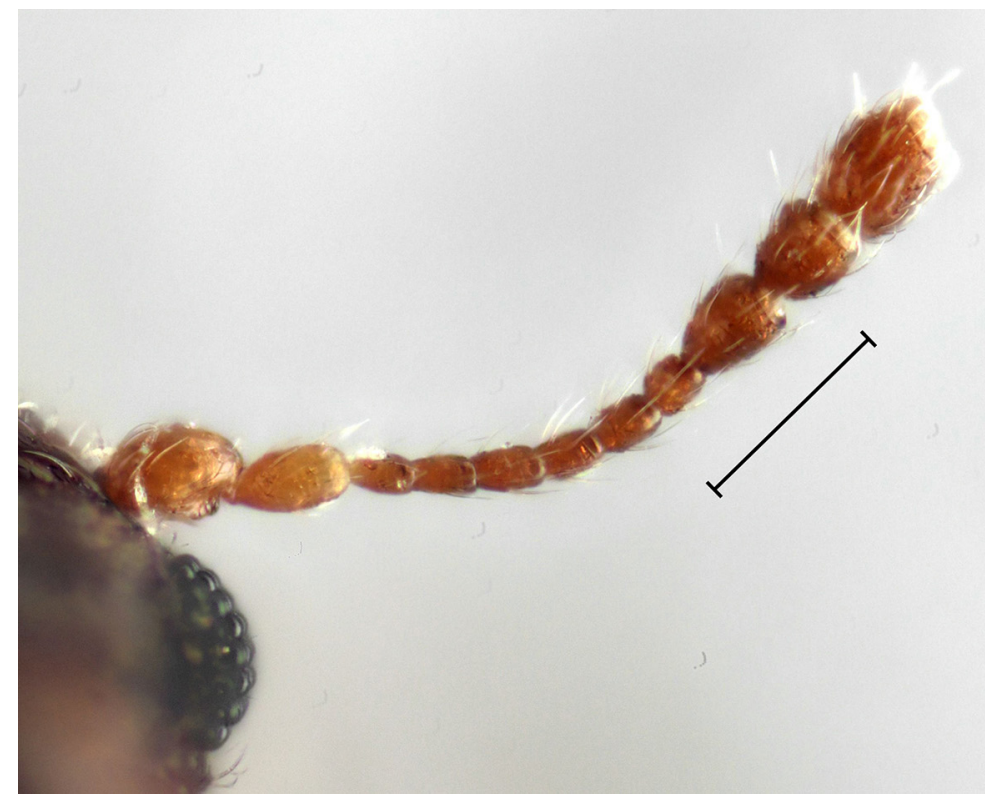

7

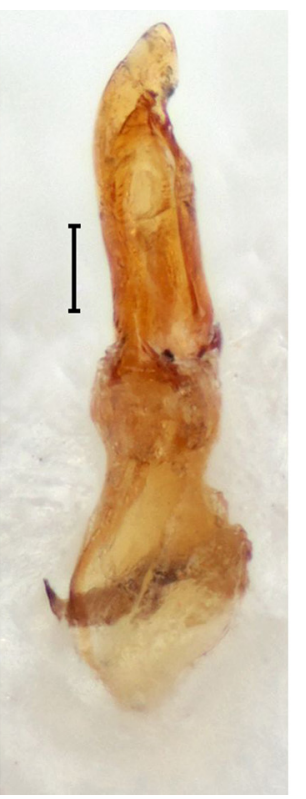

8

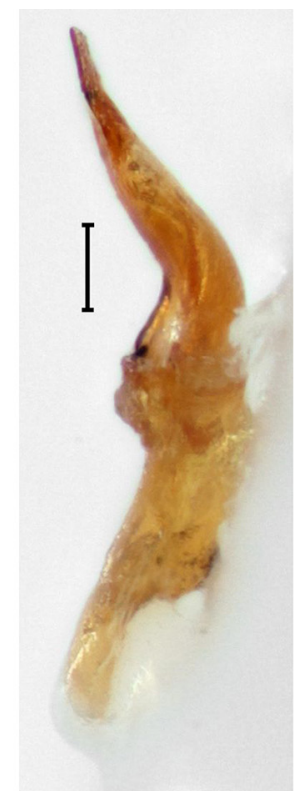

9

Figs 7-9 . Corticarina rogneda sp.n.: 7 - antenna; 8-9 - aedeagus (8 - ventral view; 9 - lateral view). Scale bars: 0.1 mm. Рис. 7-9 . Corticarina rogneda sp.n.: 7 - антенна; 8-9 - эдеагус (8 - снизу; 9 - сбоку). Масштаб: 0,1 мм. 
So, considering the the results of this study, current diversity of Latridiidae in Belarus stands at 58 species.

ACNOWLEDGEMENTS. I am very thankfull Mr. A.O. Lukashuk (Domzheritsy), Dr. I.A. Solodovnikov (Vitebsk) and Dr. O.R. Aleksandrowicz (Slupsk) for the making their unique materials available, Dr. N.B. Nikitsky (Moscow) and Dr. V.A. Tsinkevich (Minsk) for the help in studies of important materials, including the types, Mr. H.W. Rücker (Neuwied) for confirmation of the new species statuses and some literature, Dr. K.V. Makarov (Moscow) for the kind help with the imagingDr. S.K. Ryndevich (Baranawichy) for the help in manuscript preparation and my old friend Dr. A.K. Tishechkin (Washington, DC) for the help with English translation. The study was supported by Belarusian Republical Foundation for Fundamental Research (grant 515B-001).

\section{References}

Aleksandrovich O.R., Lopatin I.K., Pisanenko A.D., Tsinkevich V.A., Snitko S.M. 1996. [A catalogue of Coleoptera (Insecta) of Belarus]. Minsk. FFI RB. 103 p. [in Russian].

Bukejs A., Telnov D., Rücker H.W. 2013. Catalogue of Latvian Latridiidae (Insecta: Coleoptera)//Zoology and Ecology. Vol.23. No.4. P.312-322.

Johnson C. 2007. Family Latridiidae // I. Löbl \& A. Smetana (eds.). Catalogue of Palaearctic Coleoptera. Vol.4. Elateroidea, Derodontoidea, Bostrichoidea, Lymexyloidea, Cleroidea, Cucujoidea. Apollo Books. P.635-648.

Rücker H.W. 2013. Wiederbeschreibung und ein neues Synonim zu Corticaria aphictoides Reitter, 1898 (Coleoptera, Latridiidae) // LATRIDIIDAE. H.10. P.23-26.

Saluk S.V. 1991. [Minute brown scavenger beetles (Coleoptera, Latridiidae) of the Byelorussian fauna] // Fauna i ekologiya. Minsk: Nauka i tekhnika. P.214-220 [in Russian]
Saluk S.V. 1992. [Family Lathridiidae] // P.A. Lehr (ed.). Opredelitel' nasekomykh Dal'nego Vostoka SSSR. Vol.3. No.2. StPetersburg: Nauka. P.378-392 [in Russian].

Saluk S.V. 1995. [Contribution to the knowledge of Enicmus species related to the E. transversus (Oliv.) (Coleoptera Latridiidae)] // Fauna i sistematika. Tr. Zool. Muzeya Belorus. un iversiteta. Minsk: Nauka i tekhnika. Vol.1. P.139-145 [in Russian]

Saluk S.V. 2009. [Family Latridiidae - Minute brown scavenger beetles] // Nasekomye Lazovskogo zapovednika. Vladivostok: Dal'nauka. P.160-161 [in Russian].

Solodovnikov I.A. 1991. [Catalogue of beetles (Coleoptera, Insecta) of Byelorussian Poozer'ye]. Vitebsk: Vitebskiy Gosudarstvennyy Universitet. 37 p. [in Russian].

Tsinkevich V.A. 1998. [Review of Coleoptera from Cucujoidea superfamily from the Byelorussian part of the National Park "Belowezhskaya Pushcha"] // Parki Narodowe. Rezerwaty Przyrody. Vol.17. No.3. P.123-135. [in Russian].

Tsinkevich V.A. 2000. [New materials of fauna and ecology of beetles Cucujoidea (Coleoptera) of Belarus] // Vestnik BGU. Ser.2. Vol.3. P.60-63.

Tsinkevich V. A. 2004. [The beetles (Coleoptera) - inhabitans of fruiting bodies of basidial fungi (Basidiomycetes) of west forested zone of Russian plain (Belarus] // Byul. Moskovskogo Obshchestva Ispytatelei Prirody. Otd. Biol. Vol.109. No.4. P.17-25 [in Russian].

Tsinkevich V.A. 2005. Check List of Cucujoidea (Coleoptera) of Belarus // Contribution to Systematics and Biology of Beetles. Papers Celebrating the 80th Birthday of I.K. Lopatin. Pensoft Series Faunistica. Vol.43. Sofia. P.333-345.

Tsinkevich V.A., Aleksandrowicz O.R., Lukashenya M.A. 2005. Addition to the checklist of beetles (Coleoptera) for the Belarusian part of the Bieloweza Primeval Forest // Baltic J. Coleopterol. Vol.5. No.2. P.147-160.

Tsinkevich V.A. 2006. [Ecologo-faunistic review of Cucujoidea (Coleoptera) of Berezinsky Biosphere Reserve (Belarus)] // Byul. Moskovskogo Obshchestva Ispytatelei Prirody. Otd. Biol. Vol.111. No.2. P.26-35 [in Russian].

Tsinkevich V.A. 2007. [Conrtibution to the Fauna of Palaearctic Latridiidae (Coleoptera)] // Zoologicheskii Zhurnal. Vol.86. No.1. P.125-126 [in Russian, with English summary]. 